\title{
Haunted Histories, Animate Futures: Recovering Noongar Knowledge through Kim Scott's That Deadman Dance
}

Laura A. White

\section{(2) OpenEdition Journals}

Electronic version

URL: https://journals.openedition.org/ces/391

DOI: 10.4000/ces.391

ISSN: 2534-6695

Publisher

SEPC (Société d'études des pays du Commonwealth)

\section{Printed version}

Date of publication: 30 November 2018

Number of pages: 63-74

ISSN: 2270-0633

\section{Electronic reference}

Laura A. White, "Haunted Histories, Animate Futures: Recovering Noongar Knowledge through Kim Scott's That Deadman Dance", Commonwealth Essays and Studies [Online], 41.1 | 2018, Online since 05 November 2019, connection on 23 August 2021. URL: http://journals.openedition.org/ces/391; DOI: https://doi.org/10.4000/ces.391

\section{(c) () $९$}

Commonwealth Essays and Studies is licensed under a Licence Creative Commons Attribution - Pas d'Utilisation Commerciale - Pas de Modification 4.0 International. 


\section{Haunted Histories, Animate Futures: Recovering Noongar Knowledge through Kim Scott's That Deadman Dance}

In That Deadman Dance, Kim Scott draws on Noongar vocabulary and ontology to immerse readers in a world where rain cries and chuckles as it structures the land according to its own designs. This essay positions Scott's novel as one manifestation of his ongoing commitment to the recovery of repressed Noongar knowledge, and it formulates a framework of ecospectrality to focus attention on the recovery of repressed knowledge of the nonhuman. It contends that Scott adapts the form of the novel to circulate this knowledge to local and global readers, offering it as a resource to shape the future rather than resolve the past.

That was my concern, researching a novel: not what was, but what might have been, and even what might yet be...

Kim Scott, "A Noongar Voice” (ellipsis in original)

To be haunted in the name of a will to heal is to allow the ghost to help you imagine what was lost that never even existed [...] to long for the insight of that moment in which we recognise, as in Benjamin's profane illumination, that it could have been and can be otherwise.

\section{Avery Gordon, Ghostly Matters: Haunting and the Sociological Imagination}

Kim Scott's author biography announces that he is "proud to be one among those who call themselves Noongar," communicating his identity "as a descendant of those who first created human society" in south-west Australia (PanMacmillan). However, Scott explains that he grew up knowing little of the language and culture that constituted his heritage: "there was no traditional upbringing of stories around the campfire, no earnest transmission of cultural values" (Scott and Brown 14). Instead, he found his Noongar ancestry surrounded by silences that he has sought to remedy, in part through his conversations with Hazel Brown, a Noongar Elder with vast knowledge of Noongar language, stories and genealogies. In the collaborative work he produced with Hazel Brown, Kayang and Me (2005), Scott reflects on the role of writing in coming to terms with his cultural inheritance: "with Aunty Hazel I stood on the sandy shore of my Indigenous heritage, and sensed something substantial and sustaining waiting for me to grasp, and yet the only means I had to do so was this laying out of words upon a page" (29). Scott's language characterizes his writing as a response to a personal haunting: he senses something substantial, he feels its presence at the edge of his awareness, waiting for him in a way that he distinguishes from his previous research in archives that only allowed him access to "fossilized phrases" (28). Scott acknowledges his desire to take hold of the past by giving it a material shape, by transforming incorporeal substance into words on paper, but he also recognizes that writing itself remains a haunted medium that leaves unexpressed remainders. Scott confronts this aspect of writing as he translates Hazel Brown's oral stories into written form in Kayang and Me, and he also uses his fiction to imaginatively probe the limits and possibilities of the written word, for instance, as a central character of the novel That Deadman Dance, Bobby Wabalanginy, remarks that "some sounds had a shape on the page too... The alphabet might be tracks, trails and traces of what we said" (147). While Scott does not directly categorize 
his writing process as spectral, he does consciously reflect on the intersections among the kinds of literary work that he undertakes, ranging from community language recovery projects to novels in English, and I propose that each site of Scott's work manifests hauntings that Scott engages in order to bring repressed Noongar language and stories into contact with audiences so that this knowledge can participate in shaping alternative futures.

Scott's literary publications, including the novels True Country (1993) and Benang (1999) and his collaborative recovery work with Hazel Brown, Kayang and Me, demonstrate his consistent engagement with Indigenous histories and languages. This essay concentrates on his third novel, That Deadman Dance (2010), ${ }^{1}$ in which Scott explores his heritage by imaginatively reconstructing a pivotal moment in Noongar history: the early encounter between Western Australia's Noongar people, British settlers, and whaling crews from various other nations. As Scott discusses the composing process for this novel, a vocabulary of haunting emerges again in relation to writing: "that's what language can do. The idea of one being linguistically displaced and dispossessed, even in one's own country; and then language comes back and one makes oneself an instrument for it and for the spirit of place" (Brewster, Interview with Kim Scott 230). In this instance, Scott describes language as a kind of revenant, returning to those who have been dispossessed of their heritage, and he identifies himself as a conduit; his storytelling becomes an instrument through which ghosts return language and histories to local communities and hail wider audiences beyond, all the while revealing power dynamics of settler-colonialism that consigned Noongar language and culture to a position on the margins of Western discourse in the first place.

A model of haunting that builds from the work of sociologist Avery Gordon helps to elucidate Scott's formulation of his writing as a process of listening to the voices of others. Gordon extends the foundational work of Sigmund Freud on the uncanny and the work of Jacques Derrida in hauntology, as she builds her own conception of how haunting characterizes the contemporary world and its marginalized populations and discredited knowledges. Gordon defines haunting as "an animated state in which a repressed or unresolved social violence is making itself known," describing not only a movement across boundaries of past and present, but also an imperative to reconsider associations of vision with presence and knowledge (XVI). As Radway clarifies, the model of haunting that Gordon develops constitutes an alternative way of knowing "that is more a listening than a seeing, a practice of being attuned to the echoes and murmurs of that which has been lost but which is still present among us" (x). This theory conceptualizes the endurance of people and knowledge that have been denied mainstream visibility, and while it registers that erasure as a form of social violence, it suggests a recourse other than a return to visibility. Instead, Gordon's formulation encourages attention to ways that presence can announce itself beyond vision, surfacing through an epistemology of listening in which the knower cultivates receptivity to traces and refuses the reduction of knowledge to visual evidence.

Listening serves to bring suppressed knowledge to presence so that it can inform the actions of those who inherit it. However, the goal of conversing with ghosts differs

1. That Deadman Dance was first published in Australia in 2010. Among numerous awards, it was recognized for the 2011 Miles Franklin Award, the Victorian Prize for Literature, a regional Commonwealth Writers' Prize and the Australian Literature Society Gold Medal. 
among theorists of spectrality. For instance, Abraham and Torok develop a psychoanalytic approach to transgenerational haunting that focuses on secrets inherited from ancestors. In their framework, the secret is unspeakable because it is associated with shame or prohibitions, and the goal of speaking to the phantom becomes naming the secret to create closure and put the phantom to rest (Abraham 188; Davis 55-6). In the psychological model, individuals seek to resolve their haunting through narration that makes the past knowable and prevents its return as traumatic memory, whereas in Gordon's sociological model, haunting is conceptualized as a collective phenomenon, and the goal of speaking with ghosts is not to quiet them, but to learn to live alongside them, allowing unspeakable traces to remain to help imagine alternatives to current conditions (XVI). In accordance with Derrida's imperative to learn to live with ghosts because "no justice [is] possible without this relation of fidelity or promise, as it were, to what is no longer living or not living yet, to what is not simply present," Gordon argues that haunting activates "a potent imagination of what has been done and what is to be done otherwise" (Derrida 42; Gordon 18). In the context of Australian literary texts, Crouch similarly notes the productive potential of maintaining "haunted anxieties" and allowing the "unsettling presence" of ghosts to "structure an ongoing negotiation, a constant movement between possession and dispossession" (102, 101). Such formulations of haunting encourage dwelling with ghosts rather than exorcising them, an approach that coincides with Scott's stated desire to use his novel to explore possibilities in the past encounter not in an effort to provide comforting resolution to past conflicts, but to activate resonances that invite critical thinking about dominant historical narratives and inspire innovative thinking about the future that refuses to be "trapped in the paradigm that is being set up for us" (Brewster, Interview with Kim Scott 235).

The framework provided by Gordon illuminates haunting as an alternative way of knowing that uses previously silenced voices to guide future action; however, this framework fails to adequately address the full range of voices that become audible as a result of the Noongar language and ontology that Scott shares. In addition to mobilizing voices of ancestral others, Scott's novel circulates the voices of nonhuman others: animals, wind, rain, land and sea that are all interconnected with human kin in Noongar understandings of country. Gordon's figuration of ghosts as manifesting past violence and social erasure could be extended to build a concept of ecospectrality which attends to the return of nonhuman voices and repressed epistemologies that register these voices; such a framework would enable investigation into ways in which these voices can inspire social justice that includes accountability to human and nonhuman others. An ecospectral approach would not diminish the violence done to human populations; rather, it would expand understandings of the scope of that violence by demanding awareness of how it also carries consequences for nonhumans. As Scott demonstrates how the voices of nonhuman others haunt historical discourses of first encounter and how the novel form can be adapted to facilitate their return, That Deadman Dance reveals the intellectual and affective work ecospectrality can perform. It facilitates recognition that the repression of nonhuman voices and the Noongar knowledge that values them was not an incidental impact of colonization, but a constitutive factor; settler inhabitance required a denial of the land's vitality in order to institute a regime of property and ownership, and the novel demands that readers acknowledge this violence and confront its ongoing impacts. 
While multiple scholars foreground human cross-cultural exchange in their analysis of That Deadman Dance (Brewster, "Whiteness and Indigenous Sovereignty"; Kossew; Colomba), few include attention to the voices of nonhuman matter. Jane GleesonWhite begins to extend consideration to nonhuman subjects using an ecocritical framework; however, she argues that the novel "rewrite[s] Australia in the voice of the regional" without fully addressing the movement of knowledge across temporal or spatial scales (1). Rosanne Kennedy's essay, “Orbits, Mobilities, Scales: Kim Scott's That Deadman Dance as Transcultural Remembrance," innovatively tackles movement across scales, observing that the novel incorporates varied temporal scales "from the "social history' of the maritime frontier to the 'deep time' of the continent and the sea"; it also devotes sustained analysis to spatial scales through the instructive metaphor of orbits, which expresses how Indigenous rootedness in place co-exists with Indigenous routes that include travel, cultural exchange, and return to community (116). In another essay that develops her attention to remembrance, Kennedy analyzes intersections between oppression of humans and nonhuman animals. I share Kennedy's interest in Scott's narration of the nonhuman, and my essay attends to nonhuman matter more broadly, recognizing forces like rain and wind alongside humans and animals as members of the land community that constitutes country. Additionally, the lens of ecospectrality shifts the focus from practices of memorializing the past to the persistence of Noongar knowledge across temporal divides, despite efforts to repress it. Finally, by identifying the novel as a site of haunting, the ecospectral approach enhances attention to connections between Noongar knowledge and narrative forms, concentrating on ways Scott adapts the novel to house repressed voices and activate haunting as an affective way of knowing that challenges readers to imagine futures that include accountability to the nonhuman.

\section{Circles of Movement, Scales of Haunting}

Scott insists on the primacy of the local community, so it seems appropriate to begin tracing his engagement with ghosts by turning to that community and his language recovery $^{2}$ work. Scott founded the Wirlomin Noongar Language and Stories Project to reconnect historical archives, community elders, and descendants in order to return stories to local communities. This work operates in the mode of haunting as it confronts the past and the ways that Noongar became an endangered ancestral language not as a neutral result of change over time, but as a result of settler- colonialism which devalued Indigenous languages and knowledges while valorizing English. Scott stresses that language recovery is about returning knowledge and respect that was buried through imperialism, and he asserts that restoring language and stories can provide contemporary communities with access to precolonial narratives that inspire trust, creativity, and commitment to community in ways that dominant narratives of colonial oppression cannot. In "From Drill to Dance," Scott explains:

the consolidation of language and story in home communities in ways that strengthen and create opportunities for community members to profitably share revitalized, ancestral

2. Sue Kossew discusses the terminology of recovery, exploring the resonances of the word recovery in relationship to language work, and in relationship to Scott's fiction, since "recovery narrative" is the terminology he chooses to describe his novel That Deadman Dance, rejecting other labels such as "post-reconciliation novel" (170). 
knowledge with increasingly wider, concentric circles of people can be an important part of community development, and importantly, build something other than drawing upon the experience of oppression. (12-3)

Scott uses the image of widening circles to convey his vision that stories move through expanding circuits as they travel through community meetings, oral performance, illustrated texts, and audio and video recordings; as the circles slowly spread, repressed knowledge returns to active presence in the life of the community (and beyond). Scott's description of the movement of stories emphasizes community involvement in recalling and negotiating with the past, as members debate pronunciations and meanings, a process that also distinguishes this language recovery work from essentializing efforts to return to a pure, precolonial past of Indigenous harmony, a stereotype that Scott critiques. Rather, the Wirlomin Noongar Language and Stories Project illustrates how putting ghosts of the past into conversation with contemporary residents can empower communities to imagine futures that grow from knowledge and confidence in their heritage.

Scott offers the model of expanding circles to conceptualize his sharing of Indigenous knowledge through novels in English as an extension of his language work. Novels expand the circle to include audiences that are not part of the Noongar community, but the circle keeps the Noongar community at the center of awareness, as Scott affirms that language recovery

merely as a source of 'insight' for literature in English or indeed of perspectives unknown to wider society is of very limited value unless it also contributes in some way to the revival and continued survival of the language itself and - most especially - the wellbeing of the community descended from its speakers.

(Scott, "From Drill to Dance" 11)

Scott expresses his version of 'the 'postcolonial angst' of those who, displaced linguistically, if not geographically, write in the colonizer's tongue, for an audience of which their own people are a tiny minority," acknowledging his fraught position in relation to the genre of the novel (3). He uses the novel to pose questions about "what might yet be," and he does not shy away from the challenge: what are the consequences of using the novel form to articulate these questions? Scott's reflections about the precarious position of his novel's central character Bobby Wabalanginy, who is a performer, storyteller, and conveyor of Noongar culture, provide insight about his own position as a postcolonial novelist. Scott acknowledges that his novel comments on "the dangers of commodification versus the great power of sharing your heritage, and helping people through sharing that heritage" (Brewster, Interview with Kim Scott 240), which also reflects on his position of narrating Noongar culture through the novel, a form of storytelling that, as Edward Said has argued in Culture and Imperialism, developed not only in historical proximity to Western imperialism, but also in ideological accord with it by deploying formal features such as regulatory plot structures and patterns of narrative authority that reinforce imperial ideologies (69-71). Postcolonial writers such as Ngugi wa Thiongo have highlighted the colonial legacy of the novel and its continuing impact on Indigenous languages and cultures, while scholarship such as Graham Huggan's The Postcolonial Exotic encourages attention to the ways that publishing companies and metropolitan audiences impose expectations and commodify postcolonial writing and writers. Scott clearly recognizes this range of dangers that accompany the choice to compose a novel in English, but instead of disclaiming the novel as a colonial artifact, 
he validates his own position of strength to be able to write a novel that places Noongar people and culture at the narrative center (Brewster, Interview with Kim Scott 232). As he adapts a colonially inherited form and remakes it through interaction with Noongar knowledge, Scott's process as novelist echoes that of his character Bobby Wabalanginy, who adapts a British military drill and transforms it through his own performance.

\section{The Novel as the Haunted House of Matter}

Instead of narrating a return of knowledge to characters in a contemporary setting, Scott transports readers to the scene of the repression of Noongar knowledge. Setting the novel in the past, he recreates a world where Noongar is a vital, living language that holds a position of power, rather than presenting readers with a contemporary scene of loss or absence. He crafts a non-linear novel that moves readers back and forth across the years 1826-1844 so that they become attuned to ways in which the repression of Noongar knowledge constitutes an aspect of settler-colonial violence that is less recognizable as violence because it unfolds unevenly over time, similar to the dynamics that Rob Nixon describes as "slow violence" in the context of environmental damage. Rather than a military battle over land that occurs on specific dates, the repression of knowledge proceeds in various increments and at multiple levels from individual interactions to organized policy, and because of its accretive nature, its elements may pass unmarked as forms of violence. By opening his novel with Bobby Wabalanginy writing the Noongar word "Kaya" on a slate, Scott commences his narrative with cultural exchange already underway (1). The sections that follow move readers back and forth in time so that they witness Dr. Cross's openness to human difference as he recognizes Menak as "a very different man, of course, but a man for all that" (83), and he builds a friendship with Wunyeran which is so close that he asks to be buried in the same grave, illustrating potential for sharing and mutual respect as each adopts ideas and practices of the other. However, moments of potential are interspersed with failures and rejections such as the settler Skelly expressing disdain for the "savages $[\ldots]$ with their parrots and jabber and nakedness" (85), using animal association as a way to degrade the Noongar, discredit their language, and deny their humanity. Readers encounter the new governor instituting legal regulations that require Western dress and English language communication in the growing town, and eventually the dis-interment of Cross from the grave he shares with Wunyeran to enforce a clear dividing line between Noongar and settler, erasing Wunyeran from the town's origin story and discursively constructing the settlement over the bones of Dr. Cross: "1781-1833, Surgeon, Pioneer and Land Owner, 1826-1833, King George Town, Western Australia” (312). The novel sequences the reader's encounter with the past, and the non-linear structure complicates a typical narrative of unidirectional colonial progress or Indigenous decline, allowing the reader to inhabit moments of sharing along with moments of degradation and to comprehend changes to relationships over time. This strategy prevents any oversimplified demonization of settlers or victimization of Noongar, who appear as complex and varied characters with a range of perspectives and experiences. It offers readers the kind of opportunity Gordon theorizes to recognize repression as violence, but also to imagine how it could have been and might yet be otherwise.

The novel transports readers to the past to make the dynamics of repression tangible, and it allows readers to experience the return of repressed knowledge in the 
present. Incorporating Noongar language and ontology into a novel in English performs the kind of haunting that Gordon describes as alerting readers "that what's been concealed is very much alive and present" (XVI). The novel conjures expressions that reflect affinities between human and nonhuman matter, returning this knowledge to the local community and sharing this way of understanding materiality with global readers. For instance, the narrator includes the Noongar term "mitjal" which he defines as "a rain like tears" (313). The Noongar word conveys a sensitivity to diverse types of rain, and rather than choosing an English term such as drizzle or downpour, Scott translates the term using a comparison to tears, suggesting that the name for the type of rain expresses more than a measure of the rain's intensity; it carries the Noongar conceptualization of qualities that water and humans share. However, Scott simultaneously characterizes water in terms that extend beyond human likeness, suggesting that the water deserves respect for its own traits, not only for the ways that it resembles the human. The narrator records:

Deeper in the night the wind lifted and rain began to drum the earth. It fell and fell and fell; it gathered in the hearts of trees, in the forks of branches and cups of leaves, in clefts and cavities of rock and small indentations in the earth. Fell, overflowed, and began to move together again. (313)

This passage exhibits a grammar and vocabulary of agency that provides an alternative to Western constructions of inert matter; the rain and wind are subjects and they are paired with active verbs: they lift and drum, fall and gather for their own reasons, without reference to human agents or intentions. The movement of the water generates effects, shaping the landscape and leaving a record of its past. This description is communicated through human writing that cannot escape a human perspective or give direct access to water's voice, yet the language conveys an ontological orientation to a dynamic world in which various forms of matter share communicative abilities and agency, understood as an ability to create effects. It reveals how language can transmit a way of understanding human immersion in relationships with a living land community and how language can encourage attention to and respect for the voices and stories of nonhuman matter, for instance registering the water etching paths into the land as a story without attempting to fill all the gaps or claim total knowledge of that story.

Scott encourages readers to recognize a diversity of voices of water, wind, animal and human, refusing to subordinate nonhuman matter to the human but also refusing to collapse difference. While Scott credits both water and humans with communicative abilities, he simultaneously preserves difference and acknowledges singularity. For example, he narrates different kinds of rain, including mitjal but also the rain that spits and makes "sharp silver thorns" (3). Additionally, he distinguishes different kinds of impacts created by water. The narration "rain fell in great bodies, slamming the earth, then recovered, collected its many selves and flowed, chuckling, past flimsy houses" (314) identifies a particular, but collective body of water that chuckles at a particular group of humans: as it swirls around human construction projects and carries away a footbridge, the water laughs at the vanity displayed by some of the settlers who lack attentiveness to the water's agency and who define the ability to alter the landscape as a mark of their superior humanity (314). With these depictions, Scott revises the novel's familiar focus on individual human characters and its relegation of nonhuman matter to the role of inert background, showing how human habitation depends on sensitivity 
to and relationship with nonhuman matter and recording the consequences of ignoring these dependencies, as settler construction is destroyed by the force of the water. Crafting such narration, Scott gives readers an opportunity to learn to perceive different voices of water, while he also documents consequences of failing to listen.

Scott's attention to failures to listen coincides with accounts of Australia's ecological history and illustrates how orientation to matter influences sensory perception, and in turn, materially shapes the land in ways that continue to exert impacts. In the novel, the narrator reports that "Sometimes Wooral addressed the bush as if he were walking through a crowd of diverse personalities, his tone variously playful, scolding, reverential, affectionate," which causes his settler companions to reflect, "It was most confusing. Did he see something else?" (43). The narration implies that Wooral does indeed see something else, and his knowledge goes beyond vision: he listens to an animate land that he also engages through conversation. Beyond the novel, as Val Plumwood and William Lines separately discuss, early settlers were deaf to the sounds of unfamiliar birds, which led them to assume that Australia was lacking in bird life and to import "real" birds from home. Lines provides examples from colonial diaries that describe the "silence and tranquility," the "stillness" of the empty land (28). Plumwood uses this example to demonstrate how a Eurocentric mentality could influence the settlers' perception of the land, causing them to understand it as empty and deficient, and to act accordingly to shape it to their European ideals (65). Scott forces the reader to consider how colonizing processes operated in parallel as he presents settlers who are deaf to the communication of both human and nonhuman inhabitants, and he demonstrates the results of this deafness: a denial of their status as inhabitants that provides a justification for colonial occupation, as the settlers fence off lands and displace Indigenous peoples with the challenge, "to what use do they put this ownership as against what we have achieved in so short a time?" (Scott, That Deadman Dance 25). While Noongar language transmits conceptions of animate land, the settler construction of ownership denies the vitality and interdependency of the land community, participating in a dispossession of Indigenous inhabitants that continues to haunt modern Australia.

Scott chooses the space of the novel to recover the conflict between Noongar and settler understandings of nonhuman matter, confronting audiences with a haunting that might provide a foundation for a radical re-examination of relationships among Indigenous Australians, non-Indigenous Australians, and the nonhuman others on which their habitation depends, while it also challenges expectations about how a novel can figure Australia as haunted territory. Unlike his most recent novel Taboo (2017) and other more conventional ghost stories in which a geographic location becomes the site for resurfacing past violence in the lives of characters, in That Deadman Dance, the novel itself serves as the site for returning repressed knowledge to readers, so that instead of being absolved of the colonial past through the resolution of the plot, readers become haunted by their newly attained knowledge. This approach differs, for instance, from Tim Winton's spectral narration in Cloudstreet. Examining Winton's novel, David Crouch and Michael Griffiths respectively invoke a model of haunting and concur that Winton's use of the haunted house to figure the haunted nation runs the risk of resolving settler anxiety to allow continued inhabitance in ways that reaffirm settler-colonial ideologies. Read against what Griffiths articulates as the failure of Cloudstreet, "the recognition of dispossession as exculpation from a more radical political addressing of, and to, settler- 
colonial history and Indigenous possession" (91), That Deadman Dance complicates the haunted house trope. Scott reveals the novel itself as haunted space, exposing how the realist novel and its conventions have been complicit in silencing the voices of nonhuman matter and relegating the continuing impacts of settler colonial violence to a past that is severed from the present and the future. At the same time, he reshapes the novel so that it becomes a space where repressed knowledge can return to presence. Noongar language and ontology re-emerge within this space, unsettling settler colonial notions of home and possession by highlighting the agency of the nonhuman and the dependence of human habitation on nonhuman members of the land community. Through this ecospectral encounter, Scott not only reckons with the complexities of narrating home in postcolonial contexts; he expands notions of home as an exclusively human space, the "intimate shelter" and "private comfort" that notions of the uncanny and the haunted house typically take as their starting point (Vidler 17). Encouraging readers to reconceive rather than reconcile the violence of the repression of Noongar knowledge, Scott activates potential to imagine alternative models of inhabitance that reflect intimate connection to and responsibility for land as kin.

\section{The Future Beckons: Dwelling with Ghosts}

Scott puts ghosts into motion, and unlike novelists who seek to impose resolution by exorcising ghosts, Scott strives to create an ending for the novel that allows ghosts to remain and help design the future. Returning to distinctions between trauma and haunting illuminates Scott's narrative tactics. Cathy Caruth clarifies that traumatic memories return "insistent and unchanged" because they have never "been fully integrated into understanding" or into "a completed story of the past" and as a result, "trauma thus requires integration, both for the sake of testimony and the sake of cure" (153). Contrary to trauma theory's focus on integration, Gordon's theory of spectrality seeks to disrupt existing paradigms; instead of closing the door on the past and confining the specter within existing domains of knowledge, she urges thought to follow the ghost across constructions of past and future so that haunting enables alternative possibilities; in her words "haunting, unlike trauma is distinctive for producing a something-to-be-done" (XVI). In the case of the novel, narrating repressed Noongar knowledge does not serve to complete the story of the past; it illuminates a something-to-be-done. Anne Brewster invites Scott to discuss the novel's ending, which she admits to reading "as tragic, as filled with despair" (Brewster, Interview with Kim Scott 231). Scott returns repeatedly to this point, attempting to elucidate his hopes for creating an ending, and a novel, that neither conforms to the traditional historical script of defeat and victimization nor simply inverts that trajectory by supplying an upbeat closure. Instead, he acknowledges a desire to "set up all sorts of resonances to do with possibility and loss" and to challenge readers to take up these echoes in a way that makes "the end, the last page [...] not the end. There are possibilities still” (232). Following Scott's encouragement to embrace the possibilities, the novel can be read not as an effort to resolve the past but as an invitation to venture forward in the company of ghosts.

The closing of the novel recounts the settlers turning their faces away from Bobby's performance through which he is trying to communicate his understanding of land and his conviction that "you need to be inside the sound and spirit of it to live here properly" (349). With this closing, Scott implores readers to imagine and mourn what could 
have been if settlers had cultivated a practice of listening and had accepted the message Bobby offered through his performance. However, this scene is not the end in multiple senses. Although it appears as the final image, the novel refuses strict chronology and an older version of Bobby appears throughout the novel, continuing to tell stories to Noongar friends and to tourists. Scott indicates that Old Bobby's appearance as a storyteller throughout the non-linear novel holds out important hope for the possibility of counter-narrative (Brewster, Interview with Kim Scott 233). For example, Old Bobby continues to recount the story of the friendship of Dr. Cross and Wunyeran, refusing to let Wunyeran be erased and imagining a day when he will be memorialized alongside Dr. Cross (71), prompting readers to join him in keeping stories in motion and using them to imagine change in ways that extend beyond the pages of the novel.

Instead of leaving readers with an ending that neatly compartmentalizes the past and absolves us of the need to act, that makes recognition of past dispossession "the end," Scott's novel delivers a challenge: if we can feel the tragic failure of the past in the present, can that serve as a starting point and an inspiration to act in our world to make it otherwise? Scott's imperative to follow resonances rather than seek resolution suggests that there are many possible directions, and it would be a mistake to insist on a single path. At this stage, I will take the opportunity to trace one possible direction: the way the novel resonates with discourses of land reform. Scott grants the importance of "land, giving back land" that has been a central focus in healing relationships between Indigenous and non-Indigenous Australians (Romei), but he also implies that models of social justice that stop at the return of land miss an opportunity for a more radical engagement with the past and overlook the advantages of a more comprehensive reevaluation of conceptions of land as property. In other words, current practice operates in the mode of trauma, incorporating Noongar knowledge into existing epistemologies and listening to the voices of ghosts in an effort to resolve the violent past. The 1992 Mabo decision and 1993 Native Title Act provide the legal framework for the return of land; while Indigenous knowledge does influence legal decisions - for example, a justice in a recent mining case cited Yindjibarndi custom of requiring strangers to request permission of elders to enter and engage in activity on land as a determining factor in his decision (Gray) - the legal framework preserves paradigms of property. On the other hand, the ecospectral approach that Scott develops transforms the terrain of the novel, and in doing so, reveals ways that haunting could impact other discourses; national legal frameworks could be reshaped to reflect Noongar understandings of country and imagine modes of inhabitance that respect human dependencies on and responsibilities to nonhuman matter.

At the same time that legal frameworks continue to rely on Western conceptions of inert matter, international academic discourses such as ecocriticism, environmental philosophy, and new materialisms are developing radical engagements with nonhuman matter. Some scholars such as Val Plumwood and Deborah Bird Rose have pointed to ways that Indigenous Australian knowledge might travel beyond local communities to provide models of social and environmental justice based on mutual caring. Rose argues that Indigenous conceptions of country might support such an ethic: "Multispecies kin groups are the result of creation [...]. Within these country-based multispecies families, there is a moral proposition that is not so much a rule as a statement of how life works: a country and its living beings take care of their own" (18). Scott's novel resonates with 
such discourses, sharing Noongar knowledge with readers beyond the local community and inviting those readers to become attuned to the nonhuman voices of country which could enable alternative modes of inhabitance. However, Scott's work and his model of expanding circles also carries the reminder that such discourses must be wary of reinscribing the centrality of Western languages and knowledges by presenting Indigenous knowledge as supplement or by appropriating knowledge in ways that erase Indigenous communities as keepers of stories. Scott's strategy of prioritizing possibilities rather than creating closure confirms his commitment to stories and knowledge as growing, living things and supports his conception of the writer as a conduit that can reach across spatial and temporal divides; operating from this orientation, Scott relinquishes the authority to impose the end and beckons readers to join him in listening to recovered voices and working in concert with them to compose more equitable futures.

Laura A. WHite

Middle Tennessee State University

\section{Works Cited}

Aвraham, Nicolas, and Maria Torok. The Shell and the Kernel. Trans. Nicholas T. Rand. Chicago: U of Chicago P, 1994.Brewster, Anne. "Whiteness and Indigenous Sovereignty in Kim Scott's That Deadman Dance." Journal of the European Association of Studies on Australia 2.2 (2011): 60-71.

—. "Can You Anchor a Shimmering Nation State via Regional Indigenous Roots?" Interview with Kim Scott. Cultural Studies Review 18.1 (2012): 228-46.

CARuth, Cathy. Explorations in Memory. Baltimore: The Johns Hopkins UP, 1995.

Colomba, Caterina. "History as Sharing Stories: Crossing the Cultural Divide through Kim Scott's Fiction." Journal of Commonwealth and Postcolonial Studies 17.2 (2011): 39-56.

Crouch, David. "National Hauntings: The Architecture of Australian Ghost Stories." Journal of the Association for the Study of Australian Literature (2007): 94-105.

Davis, Colin. "État Présent: Hauntology, Spectres and Phantoms." The Spectralities Reader: Ghosts and Haunting in Contemporary Critical Theory. Ed. Maria del Pilar Blanco and Esther Peeren. New York: Bloomsbury, 2013. 53-60.

Derrida, Jacques, and Bernard STIEgLER. "Spectrographies." The Spectralities Reader: Ghosts and Haunting in Contemporary Critical Theory. Ed. Maria del Pilar Blanco and Esther Peeren. New York: Bloomsbury, 2013. 37-51.

Gordon, Avery. Ghostly Matters: Haunting and the Sociological Imagination. Minneapolis: U of Minnesota P, 2008.

GraY, Darren. "Traditional Owners Win Native Title Fight with Fortescue." Sydney Morning Herald. 20 July 2017. <https://www.smh.com.au/business/companies/native-title-win-for-wa-fortescueland-20170720-gxf78m.html>. Consulted 20 June 2018.

Griffiths, Michael R. "Winton's Spectralities or What Haunts Cloudstreet?" Tim Winton: Critical Essays. Ed. Lyn McCredden and Nathanael O'Reilly. Perth: U of Western Australia Publishing, 2014. 75-95.

Huggan, Graham. The Postcolonial Exotic: Marketing the Margins. New York: Routledge, 2001.

Kennedy, Rosanne. "Orbits, Mobilities, Scales: Kim Scott's That Deadman Dance as Transcultural Remembrance." Australian Humanities Review 59 (2016): 114-35.

—. "Multidirectional Eco-memory in an Era of Extinction." The Routledge Companion to the Environmental Humanities. Ed. Ursula Heise, Jon Christensen and Michelle Niemann. New York: Routledge, 2017. 268-77.

Kossew, Sue. "Recovering the Past: Entangled Histories in Kim Scott's That Deadman Dance." Decolonizing the Landscape: Indigenous Cultures in Australia. Ed. Beate Neumeier and Kay Schaffer. Amsterdam: Rodopi, 2014. 169-82.

Lines, William J. Taming the Great South Land: A History of the Conquest of Nature in Australia. Athens: U of Georgia P, 1999.

Ngugr wa Thiongo. Decolonising the Mind: The Politics of Language in African Literature. Portsmouth: Heinemann, 1986.

NixON, Rob. Slow Violence and the Environmentalism of the Poor. Cambridge: Harvard UP, 2011. 
Pan Macmillan Australia. "Kim Scott." < https://www.panmacmillan.com.au/author/kim-scott/>. Consulted 20 June 2018.

Plumwood, Val. "Decolonizing Relationships with Nature." Decolonizing Nature: Strategies for Conservation in a Post-colonial Era. Ed. William M. Adams and Martin Mulligan. New York: Earthscan, 2003. 5178.

RADWAY, Janice. "Foreword." Ghostly Matters: Haunting and the Sociological Imagination. Avery Gordon. Minneapolis: U of Minnesota P, 2008. VII-XIII.

RomeI, Stephen. "Forever Beginning." The Australian 22 July 2017. < https://www.theaustralian.com. $\mathrm{au} / \mathrm{arts} /$ review/aboriginal-identity-in-the-here-and-now-in-kim-scotts-novel-taboo/news-story/ ef04673ac974460c91ecffd41f874290>. Consulted 20 June 2018.

Rose, Deborah Bird. Wild Dog Dreaming: Love and Extinction. Charlottesville: U of Virginia P, 2011.

SAID, Edward. Culture and Imperialism. New York: Vintage, 1994.

ScotT, Kim. “A Noongar Voice, An Anomalous History." Westerly 53 (2008): 93-106.

—. That Deadman Dance. 2010. New York: Bloomsbury, 2013.

—. "From Drill to Dance." Decolonizing the Landscape: Indigenous Cultures in Australia. Ed. Beate Neumeier and Kay Schaffer. Amsterdam: Rodopi, 2014. 3-22.

Scott, Kim, and Hazel Brown. Kayang and Me. Fremantle Arts Centre P, 2005.

VIDLER, Anthony. The Architectural Uncanny. Cambridge, MA: MIT P, 1992. 